\title{
Experimental use of apholate to control face flies in pastures and house flies in barns
}

\author{
C. K. Dorsey
}

Follow this and additional works at: https://researchrepository.wvu.edu/ wv_agricultural_and_forestry_experiment_station_bulletins

\section{Digital Commons Citation}

Dorsey, C. K., "Experimental use of apholate to control face flies in pastures and house flies in barns" (1967). West Virginia Agricultural and Forestry Experiment Station Bulletins. 555T.

https://researchrepository.wvu.edu/wv_agricultural_and_forestry_experiment_station_bulletins/672 
West Virginia University Libraries 
Digitized by the Internet Archive in 2010 with funding from

Lyrasis Members and Sloan Foundation

http://www.archive.org/details/experimentaluseo555dors 


\section{Experimental Use of Apholate To Controlface Flies in Pastures And House Flies in Barns}

\section{Bulletin $555 \mathrm{~T}$}

October 1967

West Virginia Universify. Agriculfural Experiment Station
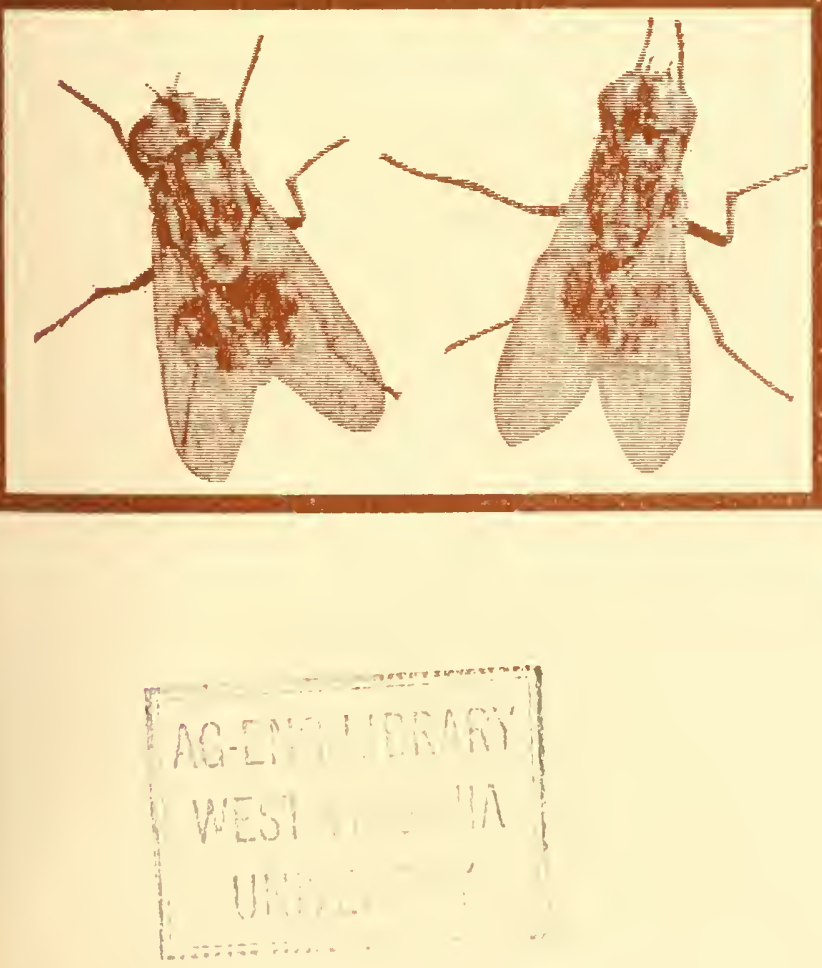


\section{The Author}

C. K. Dorsey is Entomologist, Agricultural Experiment Station.

\section{Acknowledgments}

Apholate and certain apholate baits were supplied by E. R. Squibb and Sons, Division of Olin Mathieson Chemical Corporation.

The assistance of Dr. A. E. Drake, School of Commerce and Business Administration, University of Alabama, Tuscaloosa, in processing and interpreting some of the data is gratefully acknowledgcd. The helpful suggestions and criticisms of this work offered by Dr. S. S. Ristich and Roger II. Ratcliffe are appreciated.

West VIRGINIA UNIVERSiTY

Agrigulturat, Experiment Station

Collfge of $\Lambda$ griculture and Forestry

A. H. V'inLANdinghan, DiRfetor

MORGANTOWN 


\section{Experimental Use of Apholate to}

\section{Control Face Flies in Pastures}

\section{And House Flies in Barns}

\section{K. DORSEY}

THE RESULTS of the experiments of a number of workers have indicated that flies and other insects are susceptible to the application of various kinds of chemosterilants applied topically or as an ingredient in bait (La Brecque 1961, Chamberlain 1962. Morgan and La Brecque 1962, Murrosh et al. 1964, Lindquise et al. 1964. Hair and Adkins 1964, Gouck and La Breçue I963, Ristich et al. 1965, Rateliffe and Ristich 1965, and others).

These contributions have been valuable in helping to evaluate the merits of the different materials and methods of application in efferting sterilization of insects under controlled conditions.

There is also at need for information regarding the praticality of using some of the more efficient chemicals and methods of application in the field. Several investigators (Lat Brecque et al. 1962, 1963, and fouck et al. 1963) have demomstrated that the fertility of the house Ily, Musen donestica Linnacus, was appreciably alfected when at dhemonterilan bail wils made constantly avitible under lichl conclitions.

This bulletin presents the results of exjerinents conclucted in northern West Virginia (1963 and 1964) uning apholate bats in an altempt to control the face fly, Musca antummalis De Geer, and the lono fly, Haematobia irritans (Linnileus), in pastures, and llee losuse fly in livestock barns.

Procedure and Methods of Applications of Apholate in Peastures (Face Fly Experiments lefi3). In oreler to find a lace lly atuartant we use in this investigation intensive experiments were conducted in the field in 1963 and 196.1 . Various natural substames of andmat and plant origin alone, and in combination with chenicals, were atpplicel both on and off the bodies of cows in a randomily selected block derign. Ihe 
resulas of these tests ane quite extensive and ane being published elsewhere. Prosessed ensmatic cincin hydrolyste and whole soluble bovine blood were ellertive moler lichl anditims, amel thes were selected for use in the apholate bats. Preliminatry fietd experiments using apholate for face fly control were stated late in the summer of 1963.

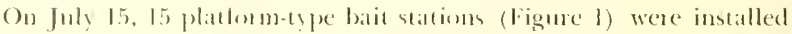
in Pasture No. 3 (70). comtabing 10 (oms) aljarent to cattle resting places. Each station comsisteal of a plywoul board (li in. squatre) painted white and monuted \& $1 \mathrm{t}$. abose the ground on posts or dead trees. Each plathom was provided with a pomanentl monmed metal pie pan (5 in. diameter) on hold the dis apholate bait. Ten dass later (August 25) al

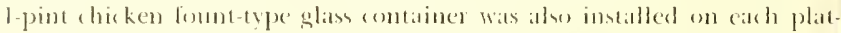
form to sontain the licpuid apholate bat. Buth types of contaliners were provided with $3 / 1$-inch mesh handwate clom lon bird shields, and eath

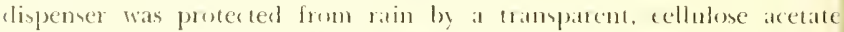
shield (Figure 1). The dry baits we replenished twice and the liquid bats once during the obervation periol (July go to september I2).

Ien apholate dry bat stations were also imsalled in Pasture No. 2 (10.1, containing 15 cows) on Ju\}y 15 in the same momner deacribed for

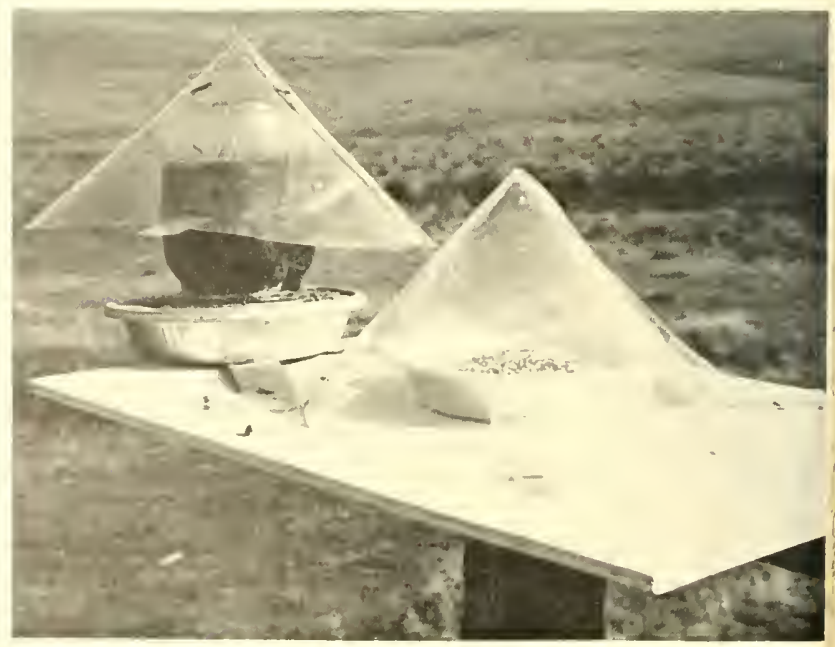

I'zente 1. Platform-type bat station. 


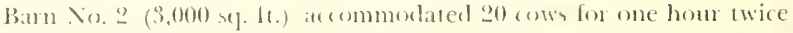

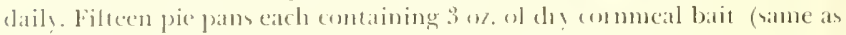

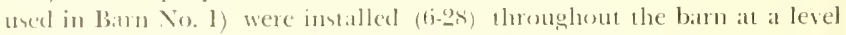

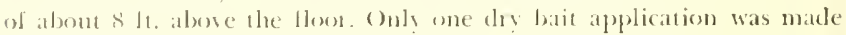
during the observation period $(7-16,109-9)$. On July $26,500 \mathrm{ft}$. of string treated (dipped amel tried) wiln an apuents (37.0 per remt) mixtue consisting of 3.0 per cent apholite, 50.0 per cent ugat, and 10.0 per cont

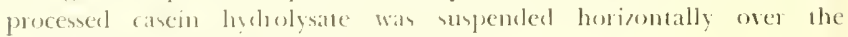
stanchions out of reath of the coms.

batn No. 3 (2,000) צy. It.) atcommolated 15 sows with pigs. On Ju]y

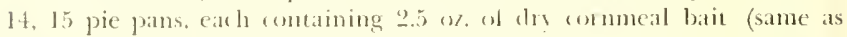
ured in Barn Vo. 1). Were installed neat the eiling on rafters around the inside of the barn. Seven imilat bat stations were intalled outside the main barn in adjacent spen sheals. These baits als were applied only ance doring the observation periox (7-3.5 10 9)-9).

Barn No. 1 (\$,0)00 sy. li.) housed lot) sow with pigs. On June 23 ,

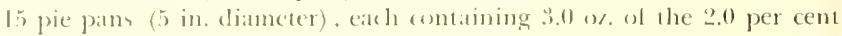

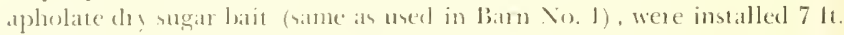
above the flow level at loxations thomghont the bann. Six hundreal fifty feet of treated cotton string (treated as described lor bam No. 2) wats installed horizmolally duough the hatn orer the hog stalls. Each apholate treatment was applicel onl) one shoing the observation perios (7-13 to (). (9) .

(Howse Fity comtrol Expeniment 1961). In 1961, two hog barns were

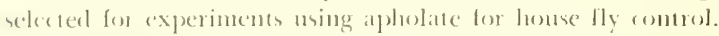

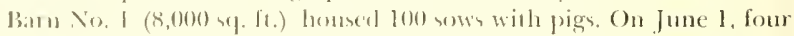

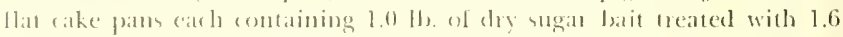

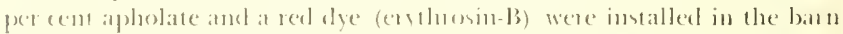

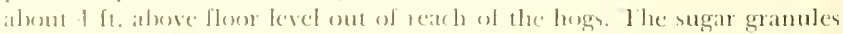

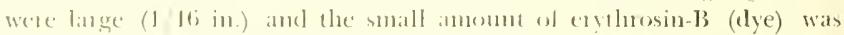

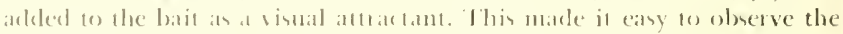

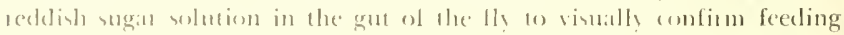

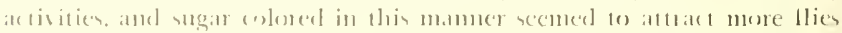

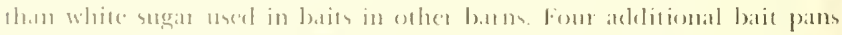

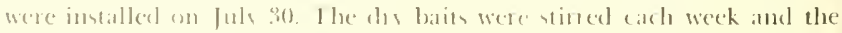

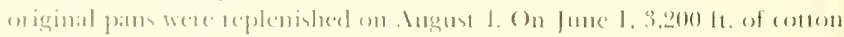

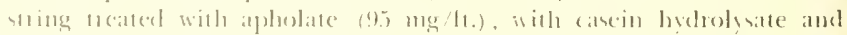

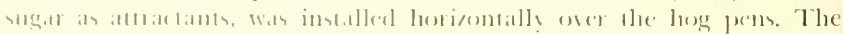

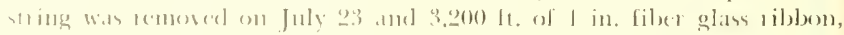

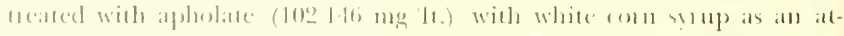
thatant, Wats installed in plate of the sting. The bann was logged with 


\section{TABLE 1}

\section{Effect of the Application of Apholate Baits in the Field on the Viability of Eggs Depasited in Manure (Face Fly Puparia Re- covered fram Manure) 1963}

Treasulut
Irerage mumber puparial recovered from 12 samples, each pasture, each of $i$ collection dates 8.7 to 9.18 .63

fintraled Pasture, \o, I

"Trealturents starte.1 in Pistures : $:$ ind 8 on $7-17-63$.

beollectons mate. two days later from 12 randumized manure deposits in which eggs were depositul in the morning after daylight: simple size approximately 1.9) yint.

"Muncin's Multiul Rilugr. Tut for $1.0 \mathrm{~g}(\mathrm{~N}+1)$ of the datal. Antilog of data means

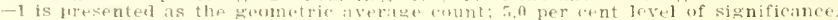

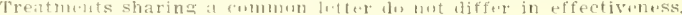

\section{TABLE 2}

\section{Effect of Apholate Baits" in the Field on the Viability of Eggs from} Field-Callected Face Flies, 1963

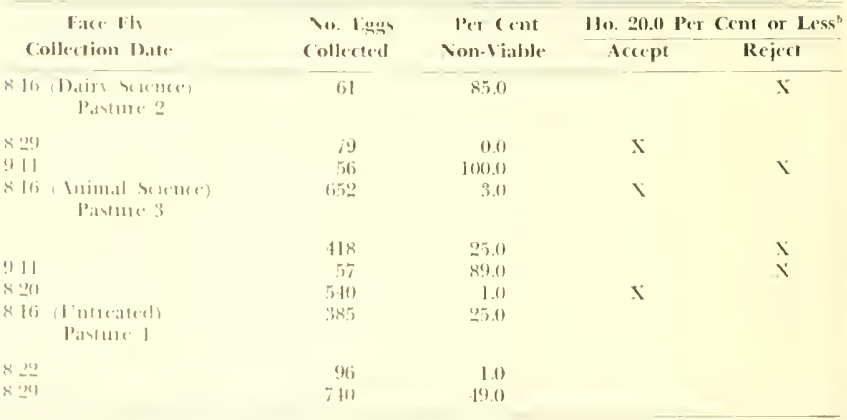

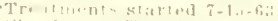

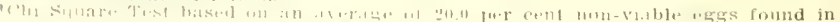

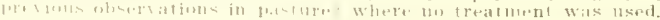

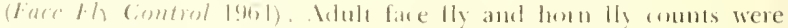

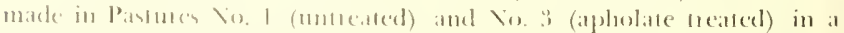

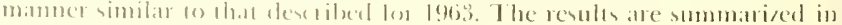
liable: $3(1961)$.

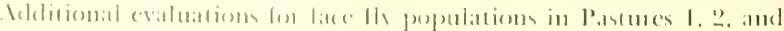

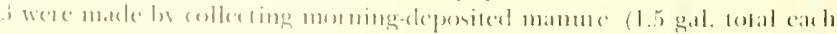

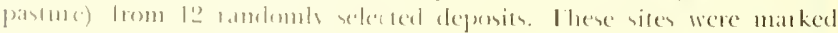


TABLE 3

Effect of Apholate Baits" in the Field on Face Fly and Horn Fly Papulations (Adult Fly Counts on Cows) 1963 and 1964

\begin{tabular}{|c|c|c|c|c|c|c|c|}
\hline Otmerasa- & Paslare & A1. $F$ & Counts & Observa. & Pasture & 1.. Fl & Counts $^{b}$ \\
\hline $\begin{array}{l}\text { tion } \\
\text { Dantes } \\
(1963)\end{array}$ & Ninmber $f$ & $\begin{array}{l}\text { Face } \\
\text { Fly }\end{array}$ & $\begin{array}{l}\text { Horn } \\
\text { Fly }\end{array}$ & $\begin{array}{l}\text { tion } \\
\text { Mates } \\
\text { (196-4) }\end{array}$ & Ninmber $\dagger$ & $\begin{array}{l}\text { Face } \\
\text { Fly }\end{array}$ & $\begin{array}{l}\text { Ilorn } \\
\text { Fly }\end{array}$ \\
\hline 7.29 & $\begin{array}{l}1 \\
\frac{9}{3}\end{array}$ & $\begin{array}{r}15.8 b^{*} \\
5.7 a^{*} \\
6.1 a^{*}\end{array}$ & $\begin{array}{l}7.2 \mathrm{~h} * * \\
0.31 \mathrm{a}^{* *} \\
9.01 \mathrm{~h}^{* *}\end{array}$ & $\left\{\begin{array}{l}6-233 \\
7 \cdot 1\end{array}\right.$ & $\begin{array}{l}1 \\
3 \\
1\end{array}$ & $\begin{array}{l}9.1 b^{*} \\
1.3 a^{*} \\
2.7 b *\end{array}$ & $\begin{array}{l}4.6 a \\
1.4 a \\
2.4 a^{* 4}\end{array}$ \\
\hline $8-6$ & $\begin{array}{l}1 \\
\frac{1}{3}\end{array}$ & $\begin{array}{r}1.3 .86 * \\
8.26 * \\
6.0 a^{*}\end{array}$ & $\begin{array}{l}7 .+16 * \\
0.37 a^{*} \\
12.21)^{*}\end{array}$ & 7.9 & $\begin{array}{l}3 \\
1 \\
3\end{array}$ & $\begin{array}{l}0.24 \mathrm{a}^{*} \\
5.7 \mathrm{~b}^{*} \\
1 .\left(1 \mathrm{a}^{*}\right.\end{array}$ & $\begin{array}{l}4.9 \mathrm{~b}, *= \\
6.9 \mathrm{a} \\
6.7 \mathrm{a}\end{array}$ \\
\hline 8.12 & $\begin{array}{l}1 \\
2 \\
3\end{array}$ & $\begin{array}{l}9.01)^{* *} \\
1.8 a^{* *} \\
6.9 b^{* *}\end{array}$ & $\begin{array}{l}4.01)^{*} \\
\text { (1).5(1):a* } \\
0.110 \mathrm{a}^{*}\end{array}$ & $\begin{array}{l}715 \\
7.23\end{array}$ & $\begin{array}{l}1 \\
3 \\
1\end{array}$ & $\begin{array}{l}2.11 a \\
2.1 \mathrm{a} \\
5.8 \mathrm{a}\end{array}$ & $\begin{array}{l}2.7 a \\
8.3 a \\
7.1 a^{* *}\end{array}$ \\
\hline 8.20 & $\begin{array}{l}1 \\
2 \\
3\end{array}$ & $\begin{array}{l}9.0 b^{*} \\
1.6 b^{*} \\
1.3 a^{*}\end{array}$ & $\begin{array}{l}\text { 5. } 2 \mathrm{~b} * \\
\left(1.1 \mathrm{a}^{*}\right. \\
9(0 \mathrm{~b} *\end{array}$ & $7-29$ & $\begin{array}{l}3 \\
1 \\
3\end{array}$ & $\begin{array}{l}1.11 \mathrm{a} \\
7.71 \mathrm{a}^{*} \\
2.4 \mathrm{a}^{*}\end{array}$ & $\begin{array}{l}19.5 h^{*} \\
2.7 a^{*} \\
21.21 b^{*}\end{array}$ \\
\hline $8-311$ & $\begin{array}{l}1 \\
2 \\
3\end{array}$ & $\begin{array}{l}7.5 \mathrm{a} \\
7.2 \mathrm{al} \\
7.6 \mathrm{ia}\end{array}$ & $\begin{array}{l}1.31)^{*} \\
11.30 \mathrm{a}^{*} \\
3.1 \mathrm{~b}^{*}\end{array}$ & $\left\{\begin{array}{l}x-7 \\
x .13\end{array}\right.$ & $\begin{array}{l}1 \\
3 \\
1\end{array}$ & $\begin{array}{l}6.7 \mathrm{a}^{*} \\
11.7 \mathrm{a}^{*} \\
7.8 \mathrm{a}\end{array}$ & $\begin{array}{l}11.7 \mathrm{a} \\
12.6 \mathrm{a} \\
7.9 \mathrm{a}\end{array}$ \\
\hline (1) 5 & $\begin{array}{l}1 \\
2 \\
3\end{array}$ & $\begin{array}{c}6.0 \mathrm{~b} * * \\
10.0 \mathrm{~b} * * \\
5.3 \mathrm{a}^{* *}\end{array}$ & $\begin{array}{l}3.810^{*} \\
11.32 a^{*} \\
3.917^{*}\end{array}$ & X.1!) & $\begin{array}{l}3 \\
1 \\
3\end{array}$ & $\begin{array}{r}3.3 \mathrm{at} \\
10.5 \mathrm{at} \\
7.0 \mathrm{a}\end{array}$ & $\begin{array}{l}21.8 \mathrm{a} \\
19.7 \mathrm{a} \\
12.1 \mathrm{a}\end{array}$ \\
\hline $9-12$ & $\begin{array}{l}1 \\
2 \\
3\end{array}$ & $\begin{array}{c}8.11 \mathrm{~b}^{*} \\
11.6 \mathrm{~b})^{*} \\
3.0 \mathrm{a} *\end{array}$ & $\begin{array}{l}12.71)^{*} \\
11.13 a^{*} \\
12 .(11)^{*}\end{array}$ & 8.26 & $\begin{array}{l}1 \\
3\end{array}$ & $\begin{array}{l}11.5 \mathrm{at} \\
12.0 \mathrm{a}\end{array}$ & $\begin{array}{l}11.01 \mathrm{a} \\
10.0 \mathrm{a}\end{array}$ \\
\hline
\end{tabular}

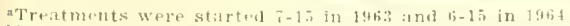

b)

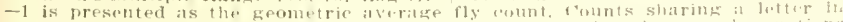

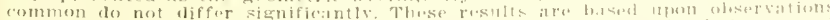

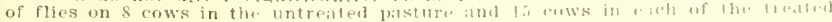
pastures.

* $1.0 \%$ level of significinc.

* +5.0\% level of signitieane.?.

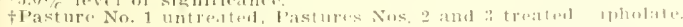

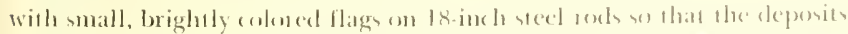

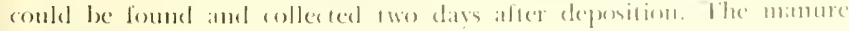

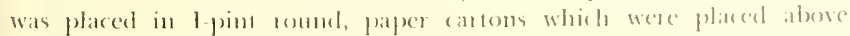

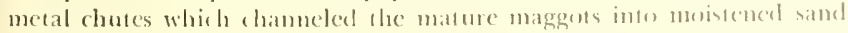

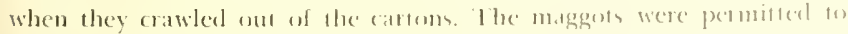

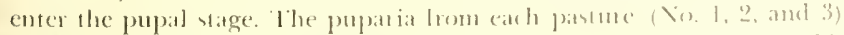

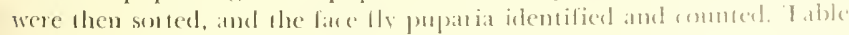

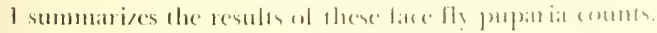

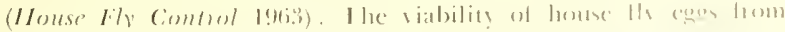

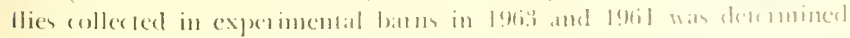


by collereting atult flies will a sweeping net in molases-feed-baited areas within the batns. The flies wese plased in seened cages provided with

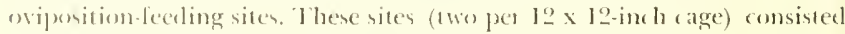
of a l-pim papes cotrum expipjest with a sugar-milk sumated section roll of absorbent paper. These sites were examined for eggs daily for at least three davs. The eggs collectal were placed in rows on moistened blotter paper in at petri dish, the top (eover) was placel on the dish, and the egge were observal daily for thee dass. The batched and unlatthed eggs were counted from each collection focation four barns in 1963 and thrce in 196.1). The results of these viability evaluations (Chi square Test) ane presented in Tables 1 and 5 . In all of the analyses, the natural, non-viable tate was designed as 20.0 per cent (in a series of observations it was detesmined that mon-riability of house fly eggs collected from flies in untreated batus ranged $1 \mathrm{rom} 16.0-20.0$ per cent). If the serility value in the experiments exceeled 20.0 per rent it was assmed that the apholite treatments alferted the viability of the oggs and the hypothesis rejected that this of curreme was by chance.

Results of Fly Gomtul Troutments (Face Fly). There were 92.0 per

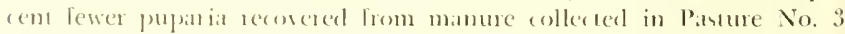
which had bouh dry and liepuid apholate bait applications than from the

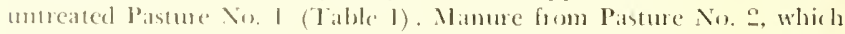
received only aly bait applications, provided about the same oumber ol

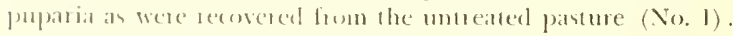

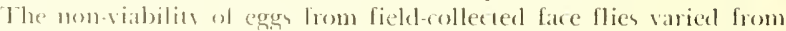
0.0.100.0 per cent in l'anture Vo. "2 (dry apholate bait) and 1.0 (n 89.0

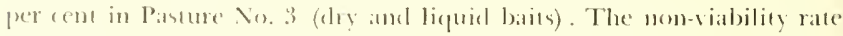
of the eggs reosered [rom llies allected in the untreated pasture ranged from 1.0 on 19.0 per cent. The highes rates of nom-viability for certain

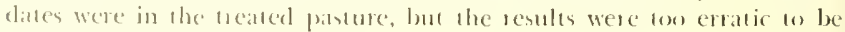
actually nignificant (lable 2) .

The apporent effect of du apholate bait on the viability of the ("gge of face and hom flies in l'astures No. 2 and 8 varied considerably (Table 3). The dfeet wat monc appousent in fate fly than in the hoon fly populatioms. Is complosed with l'asture No. J (untreated) signifiont

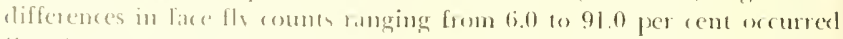

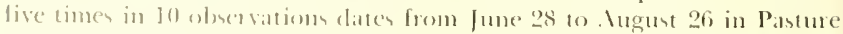
Vo. "2 (untreated). Ilair and lakins (lolid) foumel that complete sexual

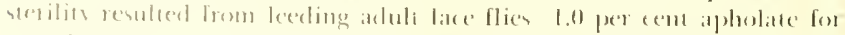

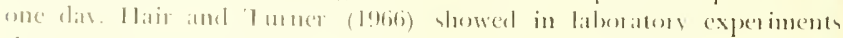
that sterility in both sexually matume and recoutl emerged fare flies an be appreciably alferted. 
TABLE 4

Effect of Apholote Treotments on the Viability of House Fly Eggs in Livestock Barns (1963)

\begin{tabular}{|c|c|c|c|c|}
\hline \multirow{2}{*}{$\begin{array}{l}\text { I. ger collection } \\
\text { Dates }\end{array}$} & \multirow{2}{*}{ Vumber lggs } & \multirow[t]{2}{*}{ Per cent Non-Viable" } & \multicolumn{2}{|c|}{ Ho. 20.11 Per Cent or Less } \\
\hline & & & Ircept & Reject \\
\hline \multicolumn{5}{|l|}{ Bam No. I } \\
\hline \multicolumn{5}{|l|}{ (11) Shere) } \\
\hline 7.15 & 15 & 0.0 & $x$ & \\
\hline \multirow[t]{3}{*}{729} & 18 & 11.11 & $\mathrm{x}$ & \\
\hline & $3 i$ & 91.11 & & $x$ \\
\hline & 19) & 160.11 & & $x$ \\
\hline \multirow[t]{4}{*}{$7-313$} & 2018 & 75.11 & & $x$ \\
\hline & 268 & (itiv) & & $x$ \\
\hline & 17.1 & (il. 11 & & $x$ \\
\hline & 3711 & 17.11 & & $\mathrm{x}$ \\
\hline 812 & 172 & 91111 & & $x$ \\
\hline \multirow[t]{3}{*}{819} & ss & 130 & $\lambda$ & \\
\hline & $\because 17$ & 1110 & v & \\
\hline & 111 & 91.0 & & $x$ \\
\hline \multirow[t]{2}{*}{8.96} & 26,3 & 28.11 & & $x$ \\
\hline & INi & $6010)$ & & $x$ \\
\hline 43 & 16.3 & $(1.1)$ & $x$ & \\
\hline \multirow[t]{3}{*}{99} & 16:2 & $3.1)$ & $\mathrm{x}$ & \\
\hline & Hiti & (x.) & $x$ & \\
\hline & 153 & 24.11 & $\mathrm{x}$ & \\
\hline
\end{tabular}

Barm 入。."

(20) (2014)

716

1798

$7=-2.96$

(nis

tis

2711

112

729

$7(16)$

Iowii

(2)iii)

녹

131

2il

Ifaij

$2-11$

(II)

$214 \mathrm{i}$

23367

91!

"ii2

il

प्र

I is

(1)

(3.1)

1.3.

(i.)

12.0

3:11

7스

제 11

[2.11

77.9

计

sifis

7.6

23.1

(i)

(2)1.1

(11) 0

111.01

i.1

(1).

(1).

(1).1)
S

$x$

$x$

N

i

X

s

$\lambda$ 
TABLE 4 (Continued)

Egg Collection Number Eggs Pex Cent Non-Vialble Ho. 24.01 Per Cent or Less Dates Accept Reject

Barn No. 3

(15 Sows with Pigs)

\begin{tabular}{|c|c|c|}
\hline 7.13 & 264 & 51.11 \\
\hline & 125 & 36.11 \\
\hline & 84 & 76.0 \\
\hline $7 \cdot 15$ & $81 i$ & 43.0 \\
\hline & 51 & $0.4 \mathrm{r}$ \\
\hline $7 \cdot 16$ & 119 & 75.6 \\
\hline 722 & 234 & 11.11 \\
\hline & 133 & 27.14 \\
\hline & 24 & 460 \\
\hline 7.23 & 19:3 & $1(\kappa), 0$ \\
\hline & $184 ?$ & 88.0 \\
\hline & 686 & 62.0 \\
\hline & 135 & $9(1.6$, \\
\hline $7 \div 29$ & $37+3$ & 71.0 \\
\hline & 2175 & 85.0 \\
\hline & 2937 & 78.0 \\
\hline & 20413 & $(19.0$ \\
\hline & 1723 & 82.0 \\
\hline \%־ & 580 & 73.11 \\
\hline & 903 & 50.11 \\
\hline 8.12 & 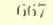 & 79.11 \\
\hline 8.12 & 777 & 19.0 \\
\hline & 281 & 12.0 \\
\hline & 173 & 970 \\
\hline $8 \cdot 19$ & 79 & 3.0 \\
\hline & $111 \mathrm{i}$ & 19.11 \\
\hline $8-26$ & (10) & 2.11 \\
\hline & 801.1 & 200 \\
\hline 8.26 & 127 & 30 \\
\hline 91.3 & 147 & 3. \\
\hline & 30.5 & 2. \\
\hline 9.9 & 111.5 & 13. \\
\hline & 1351 & 681 \\
\hline & 877 & 27. \\
\hline
\end{tabular}

Barn No. 4

(10) Sows with P'igs)

\begin{tabular}{|c|c|c|}
\hline \multirow[t]{2}{*}{7.29} & $1 i x$ & 9211 \\
\hline & 116 & 78.11 \\
\hline \multirow[t]{4}{*}{7.29} & $281 ;$ & 73.0 \\
\hline & הי1 & 8811 \\
\hline & 3110 & $\left.x^{(1)}, 1\right)$ \\
\hline & !116 & Bi.0 \\
\hline \multirow[t]{3}{*}{85} & $(170)$ & 16. \\
\hline & || $6 \mid$ & $\{13.1$ \\
\hline & 2015 & $x \geq 1$. \\
\hline \multirow[t]{2}{*}{ X.12 } & 351 & 9.11 \\
\hline & {$[\{t]$} & \\
\hline
\end{tabular}

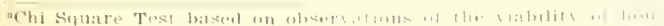
similar, untroited barns where the lowater nom-siability 


\section{Discussion and Conclusions}

One of the dilficulties in using a chemonterilant in the fickl for insect contsol in al pratical mat is the problem of ellica insts application. I he chemical must be accessible to the insert, and it has to be presented in an accpuble mannes with an atractant which can compete with the

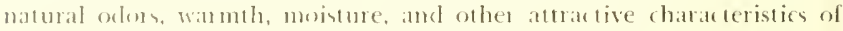
the how and the envimment. In this experiment the apholate hat to be inacessible to the hose animale (cows, sheep, and hogs) but accessible and attrative to the llies. The oxtor from the whole whlule bovine blood used in the apholate batit (for Face fly and hom fly contost in the Field) attrarted and evited the cons in an unusuat matnes, and the bat containers bad to be seumely stationed at least is ft. almove gormul to exrlude the oows. In the combol experiments with face and born llies using ap holate bats applied in the pastures, face flien were infrequently observed risiting the bats statioms, amel hon flies were rarely obsesved on any

TABLE 5

Effect of Apholate Treatments on the Viability of House Fly Eggs in Hog Barns (1964)

\begin{tabular}{|c|c|c|c|c|}
\hline \multirow{2}{*}{$\begin{array}{l}\text { Lge Collection } \\
\text { Dates }\end{array}$} & \multirow[t]{2}{*}{ Vumber legav } & \multirow[t]{2}{*}{ Cem Non-Viable' } & \multicolumn{2}{|c|}{ Ho. 20.0 Per (ent or Lew } \\
\hline & & & Accept & Rejeci \\
\hline \multicolumn{5}{|c|}{ 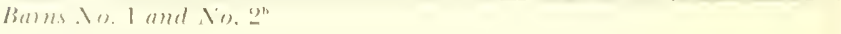 } \\
\hline \multicolumn{5}{|l|}{ (20) slatats) } \\
\hline \multirow[t]{2}{*}{6.21} & 371 & 3.0 & $\mathrm{x}$ & \\
\hline & 178 & 1.0 & $\mathrm{x}$ & \\
\hline \multirow[t]{3}{*}{6.34} & 57 & 100.0 & & $\mathrm{x}$ \\
\hline & $53 !)$ & 51.0 & & $\mathrm{x}$ \\
\hline & $1: 1$ & 55.6 & & $\mathrm{x}$ \\
\hline \multirow[t]{2}{*}{ ili } & 176 & 44.0 & & $\mathrm{x}$ \\
\hline & 301 & 72.0 & & $x$ \\
\hline \multirow[t]{2}{*}{$7-11$} & $4(1)^{2}$ & 66,0 & & $X$ \\
\hline & 381 & 68.0 & & $\mathrm{x}$ \\
\hline \multirow{2}{*}{ 7.1 } & 261 & 46.0 & & $x$ \\
\hline & 128 & 59.0 & & $\mathrm{x}$ \\
\hline 708 & 804 & 18.0 & & $\mathrm{x}$ \\
\hline \multicolumn{5}{|l|}{ lim 1 (i) 1} \\
\hline \multicolumn{5}{|c|}{ IIII) bous with P'igh } \\
\hline \multirow[t]{2}{*}{81} & 25 & 910 & & $\mathrm{x}$ \\
\hline & 87 & $8.3 .1)$ & & $\mathrm{x}$ \\
\hline \multirow[t]{2}{*}{211} & 120 & 76.0 & & $\mathrm{x}$ \\
\hline & $13 \%$ & 6.4 .0 & & $\mathrm{x}$ \\
\hline 81. & $13 i i$ & 99,11 & & $\mathrm{x}$ \\
\hline \multirow[t]{2}{*}{4 . } & 116 & 910 & & $\mathrm{x}$ \\
\hline & 126 & 98.0 & & $x$ \\
\hline \multirow[t]{2}{*}{116} & 811 & 15.0 & & $x$ \\
\hline & 61 & 340 & & $\mathrm{x}$ \\
\hline
\end{tabular}




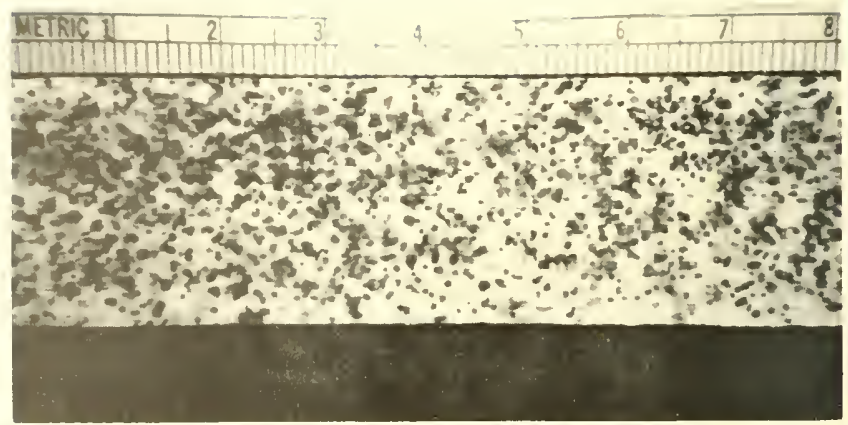

Figure.2. Apholate-sugar-treated feber glas tape showing fly visitation sprelis.

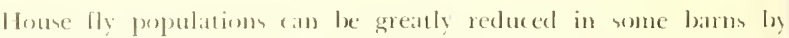

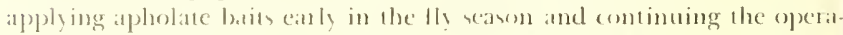
tion to the end of the seison. The viathility ol the egge of the indigenous

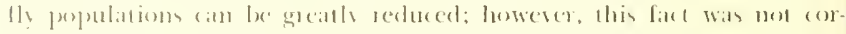

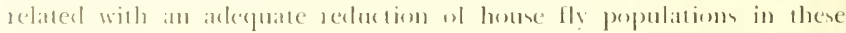

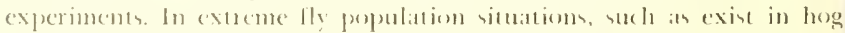

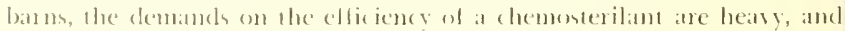

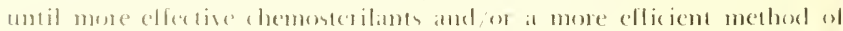

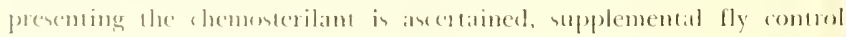

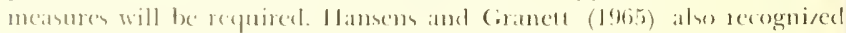

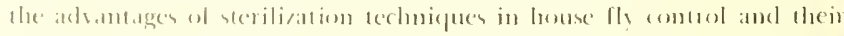

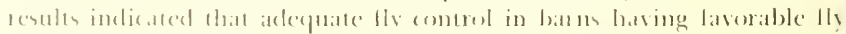

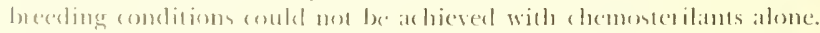

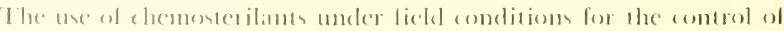
imsere peste allerting mats and osher animale has an interesting pontential

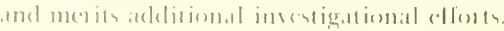


Field experiments were conducted in 1963 and 1961 uning apholate baits to control the face lly, Musca autumnalis De Geer, and the horn fly, Haematobia imitans (Limneaus), in pastures and the house fly, $M$. domestica Linnacus. in livestock barms.

In the face lly control experiment both do and liquid apholate baits were applied on elevated bait stations distributed thromghout the pastures near resting or watering sites.

The baits used in house fly control experiments in banm were ol two types. One was a dry mixture containing atpholate; in the other, cotton strings and liber glass tipes were treated with an apholate-attractant mixture. A combination of both types was usea in some of the barns.

Apholate baits applied as described allected the riability of face fly eggs, but not horn fly eggs. The viability of house fly egg, was appreciably affected in some situations and puputations nere greatly recluced in some of the barms having antinuous applisations of the baits started early in the fly seatson. 


\section{Literature Cited}

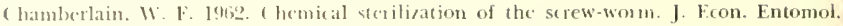
$55(2): 210.8$.

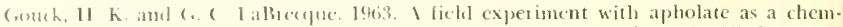

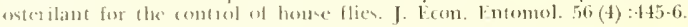

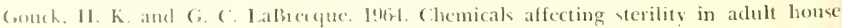

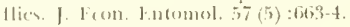

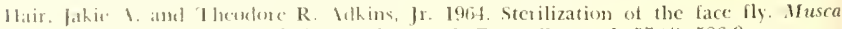
autummalis, wath aplublate and tepa. J. Econs. Fotomol. $57(-4): 586-9$.

Hair. Jakie Alexander and F. C. I'uker, Jr. 1966. Suseptibility of matme and newly emerged face flic's of demosterilization with apholite. J. Econ. Entomol. $59(2): 452-4$.

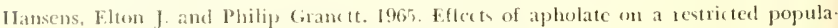
tion at heres tlics. J. Econ. Intomol. 58 (1) $: 157-8$.

Hartis, Ruber1 1. and E. D. laball. 1966. Chemosteribation of adult horn llies. J. Jeon. 1:16mul. $59(5): 1171-3$.

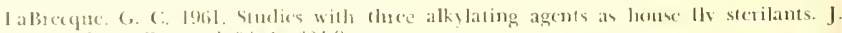
F(on. Fntomot. 51,1$):($ ist.9.

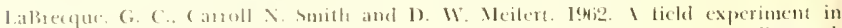
the comtsel of leste Hies with clemomerilant baits. J. Feom. Fontomol. $j 6(1) \div 149-51$.

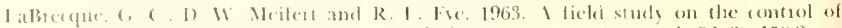

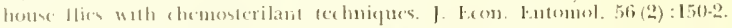

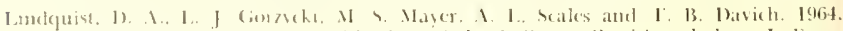

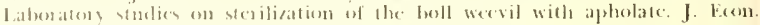
Eutomol. $57(5): 7-15-50$.

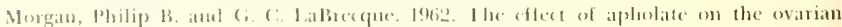

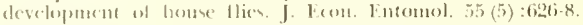

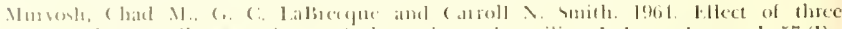

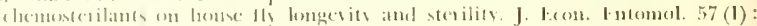
8: $9.9 ? 3$.

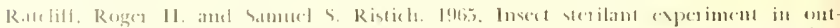

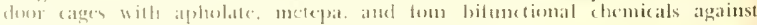
Hac homse th J. I:com. Fintomul, skitb): 1079.82.

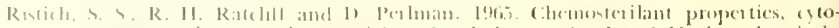

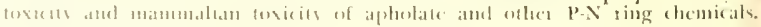
J 1 . 


\section{CAUTION}

The chemosterilant used in these experiments was apholate 2,2,4,4,6,6-hexakis (1-aziridinyl) -2,2,4,4,6,6-hexahydro-1,3,5,2,4,6-Triazatrihosphorine). It is an alkylating agent and can be dangerous if handled $\mathrm{r}$ administered carelessly. The baits were carefully dispensed so that hey were easily accessible to the flies, but inaccessible to livestock in the xperimental areas. 


